\title{
John Rawls's Appropriation of Adam Smith
}

\author{
David Johnston \\ dcj1@columbia.edu \\ Columbia University, New York, USA
}

resumo Ainda que Rawls se refira poucas vezes a $\mathrm{A}$. Smith, as idéias e argumentos de $A$ riqueza das nações são centrais para a sua teoria da justiça. Este artigo pretende mostrar que sem as idéias que Smith propõe em $A$ riqueza das nações, Rawls não teria sido capaz de escrever $A$ teoria da justiça As idéias de $A$ riqueza das nações fornecem a Rawls a questão central da teoria da justiça. Elas também fornecem o componente chave da sua resposta a esta questão, sem o qual a resposta de Rawls teria sido sensivelmente diferente. As contribuições de Smith para o conjunto das idéias que instigam Rawls a formular a sua teoria da justiça são tão importantes quanto as contribuições de Kant e são mais importantes do que as contribuições de qualquer outro pensador além de Kant (talvez com a exceção de Sidgwick).

palavras-chave J. Rawls; A. Smith; teoria da justiça

It is well-known that John Rawls's political philosophy owes a heavy debt to the writings of the eighteenth-century German philosopher Immanuel Kant. In the Preface to the original edition of $A$ Theory of Justice, Rawls describes his own theory, which he called "justice as fairness," as "highly Kantian in nature" (RAWLS, 1971, p. viii). The index to the book shows more than twenty separate references to Kant - a number that is equaled only by the number of references to Henry Sidgwick - as well as more than twelve references to Rawls's "Kantian interpretation of justice as fairness" (this is the heading under which these references are listed in Rawls's index). Rawls published two papers 
about his theory of justice with titles that included Kant's name, including the important set of three lectures he offered at Columbia University in New York under the collective title "Kantian Constructivism in Moral Theory."

In contrast, $A$ Theory of Justice contains only seven references to Adam Smith, just three of which occur in the main text (the other four are contained in footnotes) and four of which are to Smith's first major work, The Theory of Moral Sentiments. In spite of the shortage in Rawls's work of references to Smith's later and even more famous book, the ideas and arguments of An Inquiry into the Nature and Causes of the Wealth of Nations are central to Rawls's theory of justice. In fact without the ideas Smith proposed in The Wealth of Nations, Rawls would not have been able to write $A$ Theory of Justice. Smith's ideas in The Wealth of Nations supply Rawls with the central question he attempts to answer in his theory of justice. They also supply him with a key component of his answer to that question, a component without which Rawls's answer to the question would have looked sharply different. Smith's contributions to the set of ideas on which Rawls drew to formulate his theory of justice are as important to that theory as Kant's contributions and are more important to Rawls's theory than the contributions of any thinker other than Kant (with the possible exception of Sidgwick).

\section{I}

Let us first make a note of some of the most important ideas Rawls borrowed from Kant's moral theory. Kant's theory was in large part a critical response to the utilitarian tradition in moral and political philosophy. Like the utilitarians, Kant wholeheartedly endorsed the idea that all human beings are equal in worth - that, as John Stuart Mill said, everybody should count for one and nobody for more than one. However, Kant emphatically rejected the utilitarian assumption that the promotion of human enjoyment or happiness can ever serve as a foundation for sound ideas about justice. For Kant, the essential truth about human beings - the truth that is relevant to considerations of justice - is that they are free, rational, and responsible agents. The early utilitarians did not 
deny that human beings are (at least potentially) free and rational creatures. However, these attributes did not constitute the basis of their ideas about justice. For Kant, in contrast, the postulate that human beings are (potentially) free, rational, and responsible is the foundation of all sound ideas about justice and about morality as a whole.

An example Kant offers in his well-known essay on "Theory and Practice" (KANT, 1991, pp. 70-71) is emblematic of his differences with those who base their ideas about justice on the concept of utility. Imagine that a person has been made the trustee of a large estate the owner of which is deceased and the heirs to which are both ignorant of its existence and independently wealthy in their own right, while also being immensely wasteful and uncharitable. Suppose the trustee and his family of a wife and children are in dire financial straits and that the wealth contained in the estate would be sufficient to relieve them of their distress. Finally, assume that the trustee would be able, if he chose to do so, to appropriate the estate for his family's use without the possibility of his appropriation ever being discovered by the heirs or anyone else. It is clear in this scenario that the trustee would be able to increase the aggregate happiness of the concerned parties, taking into account all the heirs as well as all the members of his own family, by withholding the estate from the heirs and appropriating it for the relief of his family. He would be able to enhance the happiness of his family's members greatly without diminishing that of the heirs by even the slightest measure. Yet Kant suggests that this act of appropriation would be wrong. The trustee has a duty to distribute the estate in accordance with the will of its deceased owner and would violate that duty by directing the estate to anyone other than the intended heirs. (Notice that Kant's reasoning would lead to the same conclusion if the impoverished persons whose misery might be relieved by receiving some share of the estate were strangers to the trustee.) Despite the tug some might feel to divert the resources in question from their intended beneficiaries in order to relieve human misery, Kant argues that the trustee's duty to distribute those resources in the manner their owner intended should trump the temptation to divert the resources for the promotion of happiness. This view has been summarized pithily in the observation that for Kant, the right is (ethically or morally) prior to the good. 
On these points, Rawls adopted views that were virtually identical to Kant's views. For Rawls, as for Kant, the attribute of human beings that is important for the purposes of a theory of justice is their freedom, not their happiness. Like Kant, Rawls had no objection to the pursuit of happiness. In fact both thinkers assumed that a substantial portion of people's energies in life would be devoted to the pursuit of happiness. Unlike the utilitarians, however, neither of these thinkers believed that it is the task of a theory of justice to show how to maximize, or equalize, or in any other way increase or distribute human happiness.

Following Kant's lead, Rawls distinguishes between something he calls "the right" and something else he calls "the good." For Rawls, the good can be defined in many different ways, but the conception of the good in which he is most interested is the classical utilitarian conception, which identifies the good with happiness. Whereas Rawls associates the idea of the good first of all with the pursuit of happiness, he regards the idea of the right as the basis of justice, and like Kant, Rawls considers the right to be prior to the good. In A Theory of Justice, Rawls says that "in justice as fairness the concept of right is prior to that of the good" (RAWLS, 1971,31) and that "This priority of the right over the good in justice as fairness turns out to be a central feature of the conception" (RAWLS, 1971, 32).

Rawls's idea of the priority of the right has a major impact on the principles of justice to which his theory leads. Recall Rawls's two principles of justice as fairness:

1. Each person has an equal right to a fully adequate scheme of equal basic liberties which is compatible with a similar scheme of liberties for all.

2. Social and economic inequalities are to satisfy two conditions. First, they must be attached to offices and positions open to all under conditions of fair equality of opportunity; and second, they must be to the greatest benefit of the least advantaged members of society.

(RAWLS, 1993, p. 291)

One of the crucial features of these two principles is what Rawls calls lexical priority. According to Rawls, the first of these principles has lexical priority over the second, and the first part of the second principle has 
lexical priority over its second part. Further, when these principles are deployed to evaluate alternative possible basic structures of a society (I shall say more about this subject in a few minutes), the two principles taken together have lexical priority over all other considerations we might bring to bear on that evaluation.

Let me use the relationship between Rawls's two principles to illustrate his idea of lexical priority. For Rawls, the first of these principles has lexical priority over the second. What he means by this claim is that the first principle must be satisfied fully before the second comes into play, just as one must go through all the words that begin with the letter "a" is a dictionary before going on to the next letter. The ways in which a society's social and economic inequalities are distributed are relevant for an evaluation of the justice of that society only when all its members enjoy a fully adequate scheme of liberties.

In sum, Rawls appears to borrow from Kant 1) the assumption that the idea of freedom, rather than the notion of happiness, is the foundation of all sound ideas about justice; 2) the distinction between the right and the good; and 3) the claim that the right is prior to the good.

Rawls also borrows primarily from Kant his idea that the way to discover principles of justice for a society is to imagine a social contract among its potential members, although this idea has roots in the writings of Grotius, Hobbes, Locke, and Rousseau as well. Kant asks us to think of the civil condition or state as the product of an "original contract" agreed to by those who become its members. For him this contract is an "idea of reason" rather than an empirical or historical fact, but it is an idea of reason that in his view is of great practical import (KANT, 1991, p. 79). For Kant, the idea of the original contract is a means for determining whether or not laws and policies are just. If a law is such that a whole people could not have agreed to it in an original contract, then that law is unjust (KANT, 1991, p. 79; 99n). If on the other hand a law is such that it could have been the object of such an agreement - an agreement to which an entire people might have given its assent - then it is (at least arguably) just.

Kant limited his use of the idea of a hypothetical original contract to the task of testing the justice or injustice of laws and policies. In contrast, Rawls uses the idea of a hypothetical contract to identify a set of princi- 
ples of social justice. Rawls's use of this device is more ambitious and more elaborate than Kant's.

Rawls asks his readers to imagine that each member of society is represented by an agent in a condition he calls the "original position," a hypothetical state of affairs in which the agents come together to reach an agreement that will shape the terms on which the society operates. The object of the agents' agreement will be a set of principles of social justice focused on the distribution of advantages in the society. Because he wants his readers to imagine a hypothetical contract that will be far more ambitious (in the sense of doing more intellectual work) than Kant's idea of the original contract, Rawls provides a significantly more detailed description of the original position than Kant does of the original contract. Yet the central idea of Rawls's argument from the original position originates in Kant, more so than in Hobbes or Locke or any of the other major figures in the social contract tradition.

I have described these central ideas of Rawls's theory, all of which he borrowed mainly or entirely from Kant, in part to bring to your minds some of the main claims of Rawls's theory, and in part for the purpose of comparison. My claim in this paper, remember, is that Smith's contributions to the set of ideas on which Rawls drew to formulate his theory of justice are as important to that theory as Kant's contributions. Let me turn now to some of Smith's key ideas.

II

Adam Smith's most famous idea is that the principal source of productivity and wealth in modern commercial societies is a highly developed division of labor in which producers acquire extremely specialized skills and great efficiency. Like David Hume, Smith argued that "Commerce and manufactures can seldom flourish long in any state which does not enjoy a regular administration of justice" (SMITH, 1937, p. 862), which he equated with enforcement of property rights and contracts. But while Smith agreed with Hume that enforcement of property rights and promises is a necessary basis for any successful commercial society, he went beyond Hume in suggesting the opulence that can flow from a well- 
developed division of labor. In the opening sentence of his magnum opus Smith argues that

The greatest improvement in the productive powers of labour, and the greater part of the skill, dexterity, and judgment with which it is any where directed, or applied, seem to have been the effects of the division of labor. (SMITH, 1937, p. 3)

The improvement made possible in this way, which can be observed in the developed countries of Europe, is so great, Smith avows, that

The accommodation of an European prince does not always so much exceed that of an industrious and frugal peasant, as the accommodation of the latter exceeds that of many an African king... (SMITH, 1937, p. 12)

Smith's idea specifically is that it is the division of labor itself, rather than the efforts of individual workers taken singly, that accounts for the great bulk of the wealth generated in complex economies. Of course, all the goods that are products of labor are ultimately produced by the actions of individual workers, even if those actions are parsed into undetectably small slices. Smith's argument, however, is that the skills and efficiencies individuals contribute to a production process, whether within a single enterprise or, more importantly, within a society's division of labor as a whole, are made possible only by the fact that innumerable other persons possess and deploy their own specialized skills and achieve their own efficiencies. The skills and productivity of individuals are essential building blocks for a productive economy as a whole, of course. Yet in the absence of a complex division of labor, relatively few of the talents individuals possess would be developed into skills. The skills individuals would develop would be underutilized, and the individuals who possess them would be able to produce little more than is required for their own subsistence.

Smith's conception of the role of the division of labor in generating wealth is often cited as one of the great pillars of modern economic science. But this idea is also of central importance to modern ideas about social justice. For if the division of labor accounts for the great bulk of the productive capacities of a diverse group of people - not only by enabling them to make highly productive use of the skills they possess, but also by supplying them with opportunities and reasons for developing those skills 
in the first place - then the goods all these people produce are largely social products rather than merely the creations of individuals. More than any other single idea in the history of thought, Smith's discovery of the role the division of labor plays in the creation of wealth gave rise to the view that that wealth is overwhelmingly a social product, and not merely the sum of the products of many individual producers.

Smith's conception of the division of labor has importance beyond its role in his account of the generation of wealth, however. For Smith, a society's division of labor determines the basic contours of its social world. Those contours are constituted by a set of role definitions that prescribe entitlements and obligations for each of a society's major groups and determine its division of status and economic advantages. A sketch of these entitlements and obligations would constitute a map of the society's terrain, a guide to the locations of privilege and deprivation that are scattered throughout its population and to the patterns through which those differences are reproduced or reconstituted over time.

In the vast bulk of ancient writings that touch on questions of justice, the idea that the primary contours - the terrain - of the social world might be reshaped to conform to a human design never arises. It is true that the sophists in Athens in the fifth century B.C.E. raised a host of questions that posed a challenge to unquestioned acceptance of the existing contours of society and developed the view that political institutions and social arrangements are products of human contrivance and convention rather than being rooted in and justified through nature. Their school of thought made a radical re-imagining of the social world possible. This view retained some vitality for several centuries while it competed with the older belief that the basic contours of the social world are given by nature (a view that is dominant in the thinking of Plato and Aristotle). With the collapse of the Roman Empire in the west, however, the sense of confidence in human capabilities that was expressed in the view of the sophists and their successors eroded rapidly. Early medieval writings and practices reveal a sense of the impotence of human beings individually and collectively in the face of a world whose order and working appeared knowable only to God.

As early as the tenth century, however, we can detect signs of a gradual recovery of confidence in the capacities of humans to understand and 
to bring order to their world, largely through a recovery of Greek and Roman ideas. By the twelfth century, scholars and practitioners had begun to develop a uniform system of canon law, for which they turned repeatedly to Roman sources, and many of the texts of ancient Greek philosophy had been rediscovered from copies in Arabic that had been preserved throughout the European middle ages, texts that were translated in quantity from the thirteenth century onward. The combined impacts of logic and law demonstrated that it is possible through human devices to discern and to impose order on a world that otherwise appeared chaotic to human eyes.

The idea that the basic contours of the social world are a product of human actions and potentially an object of human design rather than being prescribed by nature stood forth at the center of the stage of early modern thought in Hobbes's Leviathan. Taking aim at Aristotle, Hobbes ridiculed the assumption that political associations are endowed by nature with an end (or in Aristotelian parlance, a "final cause"). On the contrary, Hobbes argues, a political association is a product of human artifice. That product may be unintended or deliberate, and if deliberate, it may be illdesigned or well-designed. Insofar as political associations can be perfected, that perfection will be achieved through human efforts, human knowledge, and human contrivance, not by allowing the association to grow into some imagined "natural" form.

In the second chapter of The Wealth of Nations, Smith famously remarks that the

division of labor, from which so many advantages are derived, is not originally the effect of any human wisdom, which foresees and intends that general opulence to which it gives occasion.

The division of labor for Smith is originally an unintended consequence of the actions of innumerable human beings all of whom were motivated by their own narrowly-defined objectives and none of whom foresaw the great mechanism to which their actions would ultimately lead. Yet Smith did not revert to the ancient view held by Aristotle and others that the basic contours of the social world are dictated by nature. In his view those contours are a product of human efforts. In its original form, the ultimate product is unintended by any of those who engage in these 


\section{4}

efforts. Once the division of labor has taken shape and once its shape and consequences have been understood - as Smith believed he had done a society's division of labor and the contours of the social world that stems largely from that division of labor become susceptible to deliberate reforms. In fact, The Wealth of Nations is an emphatic argument for a set of systematic reforms Smith believed would improve both the productivity and the equity of the social world that prevailed in the Scottish and British societies of his time.

In short, in The Wealth of Nations Smith developed two ideas that would play a significant role in later thinking about social justice, especially Rawls's theory of justice. The first is the idea that the wealth of any society that is based on a complex division of labor is overwhelmingly a social product. The second is the idea that it is possible for human beings to reshape the contours of their social world to accord with a human design.

Let us now turn to Rawls's theory of justice.

\section{III}

Rawls begins to lay out the most basic ideas of his theory with the following words:

Let us assume, to fix ideas, that a society is a more or less self-sufficient association of persons who in their relations to one another recognize certain rules of conduct as binding and who for the most part act in accordance with them. Suppose further that these rules specify a system of cooperation designed to advance the good of those taking part in it. Then, although a society is a cooperative venture for mutual advantage, it is typically marked by a conflict as well as by an identity of interests. There is an identity of interests since social cooperation makes possible a better life for all than any would have if each were to live solely by his own efforts. There is a conflict of interests since persons are not indifferent as to how the greater benefits produced by their collaboration are distributed, for in order to pursue their ends they each prefer a larger to a lesser share. A set of principles is required for choosing among the various social arrangements which determine this division of advantages and for underwriting an agreement on the 
proper distributive shares. These principles are the principles of social justice. (RAWLS, 1971, 4)

With this passage as a touchstone, let's now look briefly at the theory's central ideas.

The most rudimentary of all the ideas underlying Rawls's theory is the idea of society as a fair system of social cooperation among free and equal persons over time from one generation to the next (RAWLS, 1991, 4-8). He sometimes calls this the "most fundamental intuitive idea" of the theory. Rawls offers no argument to defend this idea. Instead, he assumes that his readers will accept the idea as a plausible and appealing point of departure and concentrates his creative energies on the construction of an argument on the basis of this idea rather than on its defense.

This idea, then, plays a role in his theory of justice as fairness that is similar to the role played by the fundamental intuitive ideas of geometry in geometric reasoning. Although he did not believe it possible to construct a robust and persuasive theory of justice through pure deduction, Rawls aspired to make the argument of his theory as much like moral geometry as possible (RAWLS, 1999, 403n). The fundamental ideas on which theories of this kind are based are neither true nor false, and it makes little sense to attempt to prove or disprove them. Ultimately, those ideas stand or fall because of their usefulness or lack thereof. If the propositions and theories that are based on those ideas yield plausible or compelling accounts of the subjects to which they are addressed, then the usefulness of those ideas has been demonstrated. If not, then the ideas in question may be discarded in favor of alternatives.

Rawls believed that the idea of society as a fair system of social cooperation would be appealing to his readers. For most of his career (into the early 1980s) he appeared to believe that this appeal would be universal, at least to readers who had grappled sufficiently with the arguments of his theory to grasp its main points correctly. In his later years he seemed to retreat from this assumption by suggesting that his theory is designed to appeal distinctively to people who inhabit cultures that have been shaped by democratic and liberal ideals.

It is worth noting in any case that there is nothing bland or anodyne about the proposition that society should be conceived as a fair system of 
social cooperation among free and equal persons. Rawls's theory is built on a proposition that is in fact highly controversial both in an historical and in a geographical sense. Aristotle, for one, would have been aghast at this claim. Insofar as he conceived of persons as bearers of worth, he believed that they are of radically unequal worth because they are categorically unequal in capabilities, so that the notion that we should think of society as a system of cooperation among equal persons would have made no sense to him. Nor would he have had much sympathy or appreciation for the emphasis this proposition places on freedom. For him, human beings are endowed with functions that are prescribed by nature. Excellence is exhibited through outstanding performance of those prescribed functions, much as excellence in acting is displayed through outstanding performance in a scripted role. Many pre-modern thinkers would have found the fundamental intuitive idea of society as a fair system of social cooperation among free and equal persons incomprehensible, and some would have found it reprehensible. The same things can be said of many people today who have escaped the influence of or rejected modern European ideas (they can also be said of some people who embrace modern anti-liberal European ideas). On an historical and worldwide scale, the foundation on which Rawls constructed his theory is by itself a radical proposition.

For Rawls, the idea of society as a fair system of social cooperation is a basis for reasoning about societies in what he, following David Hume, calls the circumstances of justice (RAWLS, 1971, 126-130). The circumstances of justice are circumstances of moderate scarcity, in which the hand of nature is neither so generous as to give human beings all they want with no need for labor or social cooperation, nor so harsh as to force people into a struggle for survival so elemental as to preclude social cooperation. The circumstances of justice are those in which we neither enjoy unlimited abundance nor suffer extreme deprivation.

If the fundamental idea of Rawls's theory is the idea of society as a fair system of social cooperation among free and equal persons, the key question of that theory is: on what terms should this cooperation proceed? For the purposes of his theory of social justice, Rawls thinks of society as a collaborative enterprise of a sort that is akin to a business partnership, a "cooperative venture for mutual advantage." (He did not, 
however, think of society as a voluntary association, because for the most part membership in societies is thrust upon individuals who have little or no chance either to grant or to withhold their consent [RAWLS, 2001, 4]). This conception of society is rooted in Adam Smith's contention that a complex division of labor is the principal source of the great wealth of modern societies. For Rawls, questions about social justice arise as a result of the productivity, broadly construed, that is made possible by the division of labor. As he says, "social cooperation makes possible a better life for all than any would have if each were to live solely by his own efforts." Society is a sort of partnership that is undertaken for the mutual benefit of those who enter into - or in this case, typically find that they are already partners in - that partnership. The key question of social justice is a question about the terms of this partnership, and in particular about the way in which its benefits should be distributed among the participants.

From this conception it follows that for Rawls the distributive questions to which the idea of social justice points focus distinctively on the social product, that is, on the "goods" (in a broad sense) that are generated by the joint efforts of the partners. These goods may not all be "material" or "economic" goods of the sort Smith had in mind. For example, they may include enjoyments of a non-economic kind that can be achieved only through collaboration with others, such as the enjoyments we derive from participating in a game that requires a number of participants, or from friendship. It is these goods - the diverse class of goods that are generated by the joint efforts of the partners - and these goods alone, however, for which we require a set of principles to determine the proper distributive shares.

To discover an answer to his central question, Rawls adopts the method of imagining that a society has been founded by an agreement or contract among its members that determines the terms of their association. As I mentioned a short time ago, he borrowed this method primarily from Kant. However, Kant had limited his use of the idea of a hypothetical original contract to the task of testing the justice or injustice of discrete, particular laws and policies. Rawls uses the idea of a hypothetical contract for a dramatically different purpose. For Rawls, the idea of a hypothetical contract is a device for ascertaining a set of principles of 
social justice to be applied to what he calls the "basic structure" of a just society, and to be applied only to the basic structure of a just society.

A society's basic structure as Rawls envisages it comprises its major social institutions, including its political constitution, fundamental economic structures, and principal social arrangements. For example, the institutions of private property in the means of production and competitive markets are central components in the economic structures of some societies, whereas others have been based on collective ownership of the means of production and command economies. Some countries' political constitutions provide strong legal protections for freedom of thought and liberty of conscience; others do not. The monogamous family is a bedrock social institution in many societies, while in others the polygamous family in one form or another has stood for centuries as one of society's principal social arrangements.

What does the basic structure of a society not include? In various passages Rawls takes special note of two categories of things that can be said to be just or unjust, yet are not the subjects of his theory. One of these consists of the kinds of rules that regulate interactions and transactions among private persons, such as those which regulate contractual agreements and those which apply to the practices of private associations (RAWLS, 1971, 8). The other is individual actions and transactions. These things can certainly be said to be just or unjust, but they are not the subject of Rawls's theory. His topic is social justice, and in his view the appropriate subject of a theory of social justice is a society's basic structure.

Why focus on the basic structure of society? Rawls's main argument is that the institutions and practices that comprise a society's basic structure determine how well the members of a society are able to do in life, both in absolute terms and in comparison with others. In fact, in the most precise sense it is the division of advantages that results from a society's basic structure rather than the basic structure itself that is the real subject of the theory (RAWLS, 1971, 7).

We can glean some additional features of Rawls's argument for focusing on the basic structure by looking at the following passage:

The basic structure is the primary subject of justice because its effects are so profound and present from the start. The intuitive notion here is that this structure contains various social positions and that men born 
into different positions have different expectations of life... In this way the institutions of society favor certain starting places over others.

These are especially deep inequalities. Not only are they pervasive, but they affect men's initial chances in life; yet they cannot possibly be justified by an appeal to the notions of merit or desert. (RAWLS, 1971, 7)

This passage reveals two significant points. First, in arguing for the basic structure as the appropriate subject of a theory of social justice, it is evident that Rawls's concerns about inequalities were concentrated on inequalities in people's life chances - on the (differential) opportunities available to people - and not on ultimate outcomes. He writes here of the different positions men are "born into," of their "starting places" and "initial chances." Second, the passage hints at the fact (made clearer in later discussions) that Rawls was concerned about the ways in which major social institutions shape individuals' aspirations and expectations as well as about the ways in which those institutions determine the division of advantages. Even if they have similar objective opportunities, some people do less well than others in life because they have lower aspirations or expectations. These aspirations and expectations themselves are shaped by the basic structure of society, and these subjective disparities among people were as worrisome to Rawls as objective differences in opportunities.

Nowhere in Kant's theory of justice, nor in his philosophy as a whole, do we find anything resembling Rawls's idea of the basic structure of society. Although Rawls borrowed from Kant the idea of the original contract, Rawls applied that idea to a completely different subject. Where Kant evoked the idea of the original contract as a test of whether particular laws and policies are just, Rawls uses the idea of a social contract to discover a set of principles of justice to be applied to the basic structure of society, and only to that basic structure.

Rawls's idea of the basic structure of society - the subject to which his theory of justice applies - is a version of Smith's idea of a division of labor that shapes the basic contours of the social world, thereby determining the distribution of entitlements and obligations in a society. Whether or not Rawls borrowed the idea of the basic structure of society directly from Smith, that idea is a lineal descendant of the central idea of Smith's Wealth of Nations. 
For Rawls, the basic structure is not merely one among several possible subjects of a theory of justice and social justice is not merely one among several possible types of justice. Social justice is instead justice in the most comprehensive and fundamental sense. Rawls envisages a division of labor between the principles of justice that apply to the basic structure and the rules or criteria of justice that apply to all other subjects. The principles of social justice are distinct from the rules and criteria that apply to other subjects. That is why he says that the "way in which we think about fairness in everyday life ill prepares us for the great shift in perspective required for considering the justice of the basic structure itself." (RAWLS, 1999b, 337) At the same time, those principles are also intellectually prior to these other rules and criteria and serve as a foundation for defensible ideas about justice with regard to other subjects. As he observes in $A$ Theory of Justice, once we have a sound theory of social justice, "the remaining problems of justice [including those which have to do with transactions, with criminal actions and punishments, and with compensatory justice, among other subjects] will prove more tractable in the light of it" (RAWLS, 1971, 8).

The distinction Rawls draws between the principles of justice that apply to the basic structure and the rules and criteria of justice that apply to other subjects serves an important substantive purpose for his theory of justice as a whole. One of Rawls's principal objections to utilitarianism is that it is based on a monistic conception of the good - in other words, that it fails to accord due recognition to the fact that human beings legitimately hold a plurality of conceptions of the good. In his view, classical utilitarianism is a "comprehensive" theory, that is, a moral theory that offers prescriptions for the design of human institutions as well as for the decisions individuals should make, and indeed for all subjects to which any moral theory can be applied. Kant's theory, too, is based on a set of moral ideas that Kant applies both to the actions of individuals and to rules and policies. The strong distinction Rawls draws between principles of justice that apply to the basic structure and criteria of justice for other subjects enables him to leave room for the plurality of moral views about those other subjects he believes should be accommodated by a theory of social justice, a plurality that he believes is 
not accommodated by utilitarian theories and not adequately accommodated by Kant's ideas about morality and justice.

Hence both the question Rawls attempts to answer in his theory of justice and the answer to that question are shaped profoundly by ideas that either originate in or were developed by Adam Smith in The Wealth of Nations. Rawls could not have asked the question he poses in A Theo$r y$ of Justice in the absence of Smith's claim that the overwhelming bulk of the wealth that is generated in relatively developed societies is a social product, and not merely the sum of the products of individual producers taken separately. Rawls's question is a question about the way in which that product should be distributed in a just society. Moreover, Rawls could not have answered that question in the way he does in the absence of something like Smith's conception of the division of labor and its effects on society. For Smith's conception is the direct ancestor of and the basis for Rawls's idea of the basic structure of society, which he took to be the appropriate subject of a theory of social justice.

\section{IV}

To conclude this paper, I should like to offer some brief observations that I hope will convey some sense of the important and problematic role Rawls's appropriation of Adam Smith's ideas plays in Rawls's theory.

Rawls's assertion that the basic structure of society is the appropriate subject of a theory of social justice is widely understood to be one of the most distinctive claims of his theory. As we have seen, the claim is not merely that the basic structure happens to be the appropriate subject of a theory of social justice in the same way as (say) law violations are the appropriate subject of a theory of penal justice. It is rather that the basic structure has a kind of priority over all other kinds of subjects pertaining to justice, so that social justice is justice in the most comprehensive and fundamental sense. For Rawls, a sound theory of social justice provides the necessary foundation on which we can construct solutions to other, less comprehensive problems of justice.

If we examine Rawls's arguments closely, we can see that his claim consists of three distinct parts. The first is a causal claim that the institu- 


\section{2}

tions and practices that comprise a society's basic structure determine how well the members of a society are able to do in life. The second is the conceptual claim that the principles of justice that apply to the basic structure may be quite different in character from the rules and criteria that apply to other problems of justice. The third is a claim of intellectual priority. The claim is that we can best address the wide range of questions that arise about justice by first developing a sound theory of social justice. This theory can then constitute the foundation for defensible ideas about justice with regard to other subjects.

The first of these claims in a general form is incontrovertible. How completely a society's basic structure determines how well its members are able to do may be controversial, but there can be little doubt that a society's major institutions have profound effects on its members and on the division of advantages among them.

It is not difficult to see the force of Rawls's second claim as well. Consider the example of labor contracts. In a society made up of employers who are small business owners with limited resources and employees who are independent proprietors with a significant range of employment opportunities from which to choose, we can expect that justice will be served if all parties are free to enter into labor contracts on whatever terms are mutually agreeable. Since all parties possess roughly equal bargaining power, the bargains they reach can be expected typically to be fair. Matters will be different in a society dominated by giant corporate employers with vast resources at their command and by employees who have few alternatives (or in the limiting case of some company towns, only one serious employment opportunity). Because of the great disparities in bargaining power in the latter scenario, freedom of contract is likely to lead to labor agreements that are unfair to employees. In that case collective bargaining arrangements, which reduce disparities in bargaining power between employees and employers, may restore some balance and justice to the labor contracts to which the parties agree. (In some cases, of course, collective bargaining arrangements may confer excessive power on those who bargain on behalf of employees.) A significant shift in perspective is required to grasp the fact that fairness is best secured in situations of great disparity in bargaining power by arrangements that differ sharply from those which typically lead to fair 
bargains in situations of relatively equal bargaining power. It is not surprising that a similar or greater shift in perspective may be required to grasp the fact that fair principles of justice for the basic structure of a society may differ markedly from the rules or criteria of justice that apply to ordinary interactions among individuals.

The third claim that is embedded in Rawls's assertion that the basic structure of society is the appropriate subject of a theory of social justice is more problematical. This is the claim that the principles of social justice are intellectually prior to and serve as a foundation for defensible ideas about justice with regard to other subjects. Consider for another brief moment the example of labor contracts. If agreements reached by employers and employees who possess roughly equal bargaining power under conditions of freedom of contract are likely to be fair, the reason for this fact is that those agreements typically will embody the norm of balanced reciprocity, according to which relations among relative equals are just when those equal persons exchange things that are of equal value, whether these things are benefits or harms. If collective bargaining arrangements help to restore fairness under conditions of highly unequal bargaining power, the reason is that those arrangements bring labor agreements more nearly into line with the norm of balanced reciprocity.

Nothing is more central to the way in which human beings think about fairness among relative equals than the norm of balanced reciprocity. In a chapter in A Theory of Justice on "The Sense of Justice," Rawls observes that "reciprocity, a tendency to answer in kind... is a deep psychological fact... A capacity for a sense of justice built up by responses in kind would appear to be a condition of human sociability" (RAWLS, 1971, 494-95).

The kind of reciprocity Rawls has in mind here is balanced reciprocity, "a tendency to answer in kind." Although the justice of collective bargaining arrangements is not intuitively obvious to most people, the argument for the justice of those arrangements rests on intuitions that are highly accessible as well as widely, perhaps even universally, shared. The same thing can be said of the principles of social justice, as Rawls seems to acknowledge when he observes that the "most stable conceptions of justice are presumably those for which the corresponding sense of justice is most firmly based on these tendencies" (RAWLS, 1971, 495). 


\section{4}

In short, while it seems sensible to claim both that a society's basic structure plays a large causal role in determining how well its members are able to do and that the principles of social justice may be distinct from those which apply to other subjects, it is misleading to suppose that the principles of social justice are intellectually prior to and constitute the foundation for ideas about justice in relation to all other subjects. The kind of justice that applies directly to relations among persons is not trumped by the principles of social justice. Instead, the principles of social justice are rooted in the idea of justice in direct relations among persons. This idea - that justice among relative equals is based on the norm of balanced reciprocity - possesses an integrity that is not overshadowed by, and in fact provides the intellectual foundation for, sound ideas about social justice. Principles of social justice are distinct from the principles that apply to direct relations among relative equals because the complexity of social institutions and practices requires adjustments to those principles. Ultimately, however, sound principles of social justice will be based on the norm of balanced reciprocity among relative equals.

If sound ideas about social justice are rooted in the norm of balanced reciprocity, then the concept of desert, which Rawls dismisses perfunctorily, may have a role to play in the way we think about justice, including social justice, after all. If two persons, $\mathrm{A}$ and $\mathrm{B}$, are relative equals, and $\mathrm{A}$ confers a benefit on $\mathrm{B}$, then there is a sense in which $\mathrm{A}$ deserves to be requited with a benefit similar in value to the benefit she has conferred and $\mathrm{B}$ has an obligation of justice to bestow a benefit on $\mathrm{A}$ in return for the benefit he has received. Similarly, if $\mathrm{Q}$ inflicts a harm on $\mathrm{R}$, then there is a sense, independent of any particular conception of social justice, in which $\mathrm{Q}$ deserves to suffer some harm in return.

Of course, the norm of balanced reciprocity in its simplest form - the form that applies to bilateral relations between relative equals - is not adequate as a guide to justice in relations among persons in circumstances that are complex. In situations that are multilateral or in which people are unequally placed, the social arrangements that would lead to justice in relations among persons may be dramatically different from those which apply to simple bilateral relations between equals. To accommodate these situations, major adjustments are needed in much the same way as adjust- 
ments are required in bargaining between employees and employers when the disparities in bargaining power between them are large.

We can therefore see how the concept of desert might play a significant role in the way we think about justice without leading us to endorse either the principle of desert or retributivist reasoning in its classic form. Rawls was right to see that the principles of justice that apply to the basic structure of a society are conceptually distinct from the rules of justice that apply to simple bilateral relations between persons. In fact his insight is generalizable to many subjects in addition to the basic structure of society. Yet regardless of the particular subject for which they are designed, if principles of justice are to be recognizable and acceptable to human beings, they must be rooted in the sense of justice, a sense that is best expressed through the concepts of reciprocity and desert.

${ }^{1}$ Professor do Departamento de Ciência Política da Columbia University.

\section{Sources}

Aristotle. 1960. The Politics of Aristotle, trans. with notes by Ernest Barker. Oxford: Clarendon Press.

Hobbes, T. 1997. Leviathan: A Norton Critical Edition, ed. by Richard E. Flathman and David Johnston. New York: Norton.

Kant, I. 1991 "On the Common Saying: 'This May be True in Theory, but It Does Not Apply in Practice,' in Political Writings, ed. Hans Reiss, trans. H. B. Nisbet, $2^{\text {nd }}$ ed. Cambridge: Cambridge University Press.

Kant, I. 1991b. The Metaphysics of Morals, trans. Mary Gregor.

Cambridge: Cambridge University Press.

Rawls, J. 191. A Theory of Justice. Cambridge, MA: Harvard University Press, 1971

Rawls, J. 1999. “Justice as Fairness: Political not Metaphysical,” in 
Collected Papers, ed. Samuel Freeman. Cambridge, MA: Harvard University Press, 1999

Rawls, J. 1999b. "Kantian Constructivism in Moral Theory," in Collected Papers, ed. Samuel Freeman. Cambridge, MA: Harvard University Press.

Rawls, J. 1993. Political Liberalism. New York: Columbia University Press.

Rawls, J. 2001. Justice as Fairness: A Restatement, ed. Erin Kelly. Cambridge, MA: Harvard University Press.

Smith, A. 2001. The Theory of Moral Sentiments, ed. D. D. Raphael and A. L. Macfie. Oxford: Clarendon Press.

Smith, A. 1937. An Inquiry into the Nature and Causes of the Wealth of Nations, ed. Edwin Cannan. New York: Modern Library. 